\title{
ANALYSIS OF THE DYNAMICS OF COASTAL LANDFORM CHANGE BASED ON THE INTEGRATION OF REMOTE SENSING AND GIS TECHNIQUES: IMPLICATIONS FOR TIDAL FLOODING IMPACT IN PEKALONGAN, CENTRAL JAVA, INDONESIA
}

\author{
Fajar Yulianto (D) , SuWArsono (D) , Taufik Maulana, \\ MuHAMMAD ROKHIS KHOMARUdiN (10
}

Remote Sensing Application Centre, Indonesian National Institute of Aeronautics and Space (LAPAN), Jakarta, Indonesia

Manuscript received: March 15, 2018

Revised version: July 10, 2019

\begin{abstract}
Yulianto F., Sumarsono, Maulana T., Khomarudin M.R., 2019. Analysis of the dynamics of coastal landform change based on the integration of remote sensing and GIS techniques: Implications for tidal flooding impact in Pekalongan, Central Java, Indonesia. Quaestiones Geographicae 38(3), Bogucki Wydawnictwo Naukowe, Poznań, pp. 17-29. 13 figs, 4 tables.

ABSTRACT: Coastal landforms are located in the interface zone between atmosphere, ocean and land surface systems formed by the geomorphic process of erosion, depositional, and subsidence. Studying the dynamics of coastal landform change is important for tracing the relationship between coastal landform changes and tidal flooding in the coastal areas of Pekalongan, Indonesia. The method of integrating remote sensing data with geographic information system (GIS) techniques has been widely used to monitor and analyze the dynamics of morphology change in coastal landform areas. The purpose of this study is to map the dynamics of landform change in the study area from 1978 to 2017 and to analyze its implications for the impact of tidal flooding. The results of the mapping and change analysis associated with coastal landforms can be classified into four landform types: beach, beach ridge, backswamp and alluvial plain. Changes in coastal morphology and landform topography affected by land subsidence and changes in land use/land cover have contributed to the occurrence of tidal flooding in the study area. Beach ridges perform an important role as natural levees which hold back and prevent the entry of seawater at high tide in coastal areas. A limitation of this study is that, as it focuses only on the physical aspects of coastal landform characteristics for one of the factors causing tidal flooding.
\end{abstract}

KeY words: Coastal landform, tidal flooding, remote sensing - GIS, Pekalongan, Central Java, Indonesia

Corresponding author: Fajar Yulianto fajar.yulianto@lapan.go.id

\section{Introduction}

A landform is a natural geographical feature of the Earth's surface that has typical relief characteristics, which reflect the structure of the Earth's crust and the natural processes that work upon it. Landforms are created and shaped by natural geographical forces that have different characteristics in terms of their structure, geomorphological process, relief/topography and constituent materials (Blaszczynski 1997, Rao 2002, Brooks 2007). Coastal landforms occur in the dynamic zone at the interface between the three major natural systems of the Earth's surface: atmosphere, ocean and land surface (DavidsonArnott 2010). Such landforms are sensitive to erosion and depositional processes as a result of the influence of waves, coastal currents, the wind, 
sediment transport and anthropogenic activities. They express the characteristics of existing coastal processes and are formed over long time scales (Chandrasekar et al. 2000, Kaliraj, Chandrasekar and Ramachandran 2017).

Remote sensing data integrated with GIS techniques have been widely used to monitor and analyze the dynamics of landform changes. Many change detection approaches based on the integration of remote sensing data and GIS techniques, including visual interpretation (Shalaby and Tateishi 2007, Zhao et al. 2008), spectral value change (differencing, image regression, digital number value analysis) (Ekercin 2007, Erkkilä and Kalliola 2004), multi-source data analysis (Marfai et al. 2007), automatic change detection (Kuleli et al. 2011), and change vector analysis (Lambin and Strahlers 1994), are currently used to map and analyze landforms.

Pekalongan is located in the coastal area of Central Java, Indonesia. The dynamics of the development of coastal landforms in the area are extensive and rapidly changing as a result of land use requirements (Ismail 2012). Tidal flooding (known locally as $r o b$ ) is one of the phenomena that impact on environmental, social and economic conditions in coastal areas of Pekalongan. These occurrences make economic facilities, infrastructure and public health failure to be operated. It also degraded prices for land and housing as well as increasing poverty, unemployment, dirty and slum environments. In addition, according to Marfai (2014), other areas affected by tidal flooding in coastal Pekalongan includes mangrove ecosystems, agriculture and aquaculture, and these impacts have become widespread due to rising sea levels. Figure 1 shows the impact of tidal flooding on environmental conditions and inadequate road infrastructure as a result of tidal flooding in Mulyorejo Village, Tirto District, Pekalongan Regency.

The limited information available related to the dynamics of change in coastal areas of Pekalongan is an obstacle stopping and releasing tidal flood occurrences and its reducing impacts. In order to provide spatial information of the dynamic changes and related to the frequently current occurrences of tidal floods the study is carried it out. Related to this the study is conducted to trace the dynamic changes of Pekalongan coastal areas by the integration of remote sensing

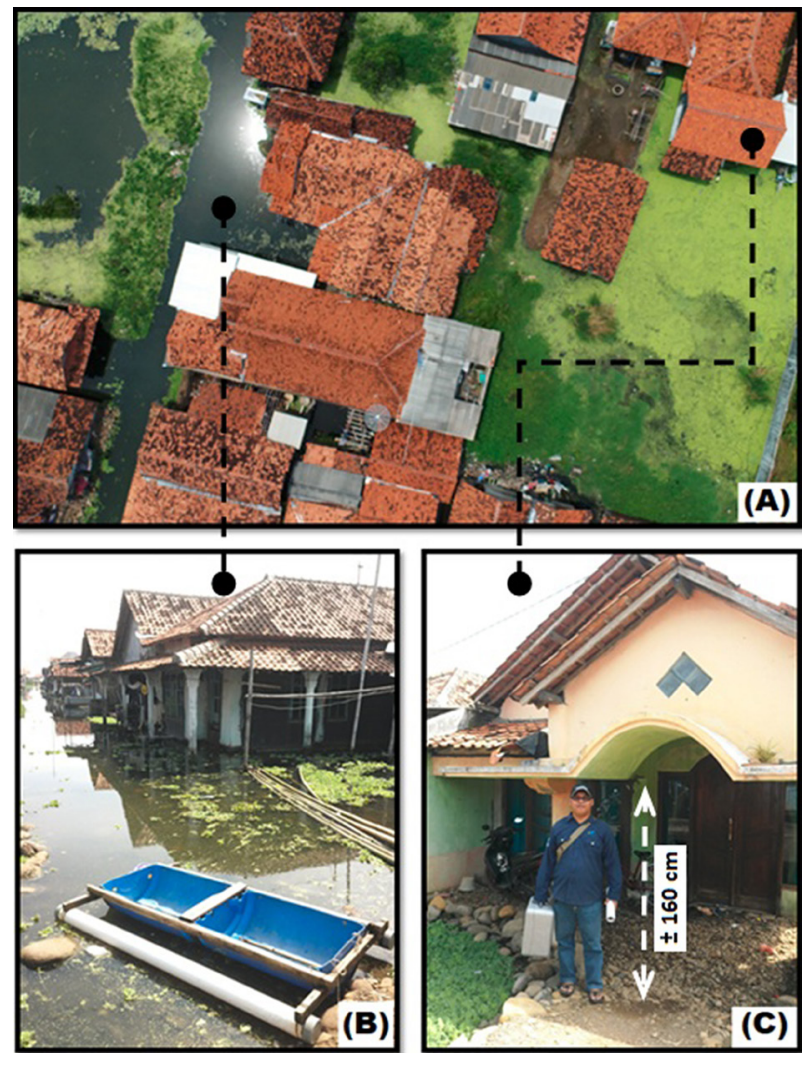

Fig. 1. Environmental conditions in one of the locations affected by tidal flooding in Mulyorejo Village, Tirto District, Pekalongan Regency. (Photos and drone mapping by Yulianto, 2017).

A. Tidal flooding seen from a height of $50 \mathrm{~m}$ using drone mapping; B. Non-functioning road infrastructure and inundated houses; C. Community adaptation efforts in dealing with the impact of tidal floods by piling up soil, sand and stone in the yard of a house.

data and GIS techniques. It is assumed that the uses of a bundle sets of satellite images and GIS data enables to characterize and identify of dynamic coastal landform change by mapping, analyzing and its impacts. By doing this study, it might trace the probable existence of the relationship between the occurrence of coastal landform changes and tidal flooding in the Pekalongan coastal area.

This study was also conducted as part of the effort to overcome the problem of flood tides occurrences. The study has been focusing to prove that coastal landform changes ware one of the causes of tidal flooding in Pekalongan. Moreover, the results of this study can be used as input data for the planning of coastal hazard assessments and recovery as well as can be used as a model for same cases occurrences in other location around Indonesia. 
In general, this study has provided information related to the results of mapping and analysis of the dynamics of coastal landform changes during the period 1978 to 2017 and its implications for tidal flooding impact in the study area. The details of the purpose of this study are to:

- map and model the dynamics of coastal topographical changes,

- to map the dynamics of coastal landform changes,

- to analyze the effect of coastal landform change and related implications of tidal flood impact in the study area.

\section{Study area}

According to Marfai (2014) and Bemmelen (1949), Java is a volcanic island comprising a thousand volcanoes in its central spine and a fault area in the northern lowlands. Meanwhile, a limestone karstic plateau dominates the south of the island. Lowland topography and low ocean waves attract inhabitants, and thus coastal cities like Jakarta, Semarang and Surabaya are experiencing urbanization. The research area is located in Pekalongan which is in one of the northern coastal areas of Central Java, Indonesia at coordinates $6^{\circ} 51^{\prime} 00^{\prime \prime} S-6^{\circ} 54^{\prime} 00^{\prime \prime} S$ and $109^{\circ} 36^{\prime} 00^{\prime \prime} \mathrm{E}-109^{\circ} 43^{\prime} 00^{\prime \prime} \mathrm{E}$. In general, the geological formations in the study area are alluvial deposits derived from rivers and swamps and beaches with a thickness of up to 150 m consisting of gravel, sand, silt and clay (Condon et al. 1996).

\section{Materials and methods}

\section{Data availability}

In this study, remotely sensed data were used to perform coastal landform mapping via multi-temporal changes in morphological analysis. Landsat data, with a resolution of $30 \mathrm{~m}$ at Level 1 Geometric (L1G) (Fig. 2) with sensor MSS (path/row: 120/65) was used as the input data for 1978 while TM sensor data was used for 1988, 2007 and 2011. The ETM + sensor was used as the input data for 2000 and OIL/TIRS sensors was used as the input data for 2017. Landsat MSS and Landsat 5 TM data were provided by the US Geological Survey (USGS) and Landsat 7 ETM + and Landsat 8 OLI/TIR data were provided by the Remote Sensing Technology and Data Center, LAPAN. In addition, this research also required high-point data from topographic maps obtained from the Indonesian Geospatial Information Agency (BIG). These data are used as inputs for topographic modelling to show vertical morphological changes in the study area.

\section{The dynamics of coastal topographical mapping and modeling}

Topographic conditions in the study area can be represented and simplified using the digital elevation model (DEM), which was created using high-point data from the topographic map at scale 1:25,000, obtained from BIG. The data provides high-point information for 1998 spread evenly across the study area. A high-point interpolation approach using inverse distance weighted for $30 \times 30 \mathrm{~m}$ was used to create DEM mapping of the study area. Furthermore, topography or DEM current (2017) and previous-year (1978, 1988, 2000, 2007 and 2011) conditions can be modelled using Equation (1) as in previous research by, for example, Marfai and King (2007) and Ward et al. (2010). Rate of subsidence is also needed for DEM modelling and in this study this rate $\left(3 \mathrm{~cm} \mathrm{yr}^{-1}\right)$ on average (Fig. 3 ) was obtained based on the research carried out by Nashrrullah et al. (2013).

$$
\text { Land }_{T(x)}=\text { Land }_{T(0)}-\left(\text { LandRate } / 100 \times\left(T_{x}-T_{0}\right)\right.
$$

where Land $_{T(x)}$ is the DEM at the time $(T)$ in the year $(x)$. Land $_{T(0)}$ is the DEM in the reference or baseline year $T_{0}$. LandRate is the rate of subsidence in metres, spatially. $T_{x}$ is a given year and $T_{0}$ is the year 1998, where the last update for DEM data was made.

\section{Coastal landform mapping and change analysis}

The coastal landform mapping was prepared based on visual and digital interpretation of Landsat images. The estimation of coastal landform features was performed using an on-screen digitizing approach for Landsat image colour 

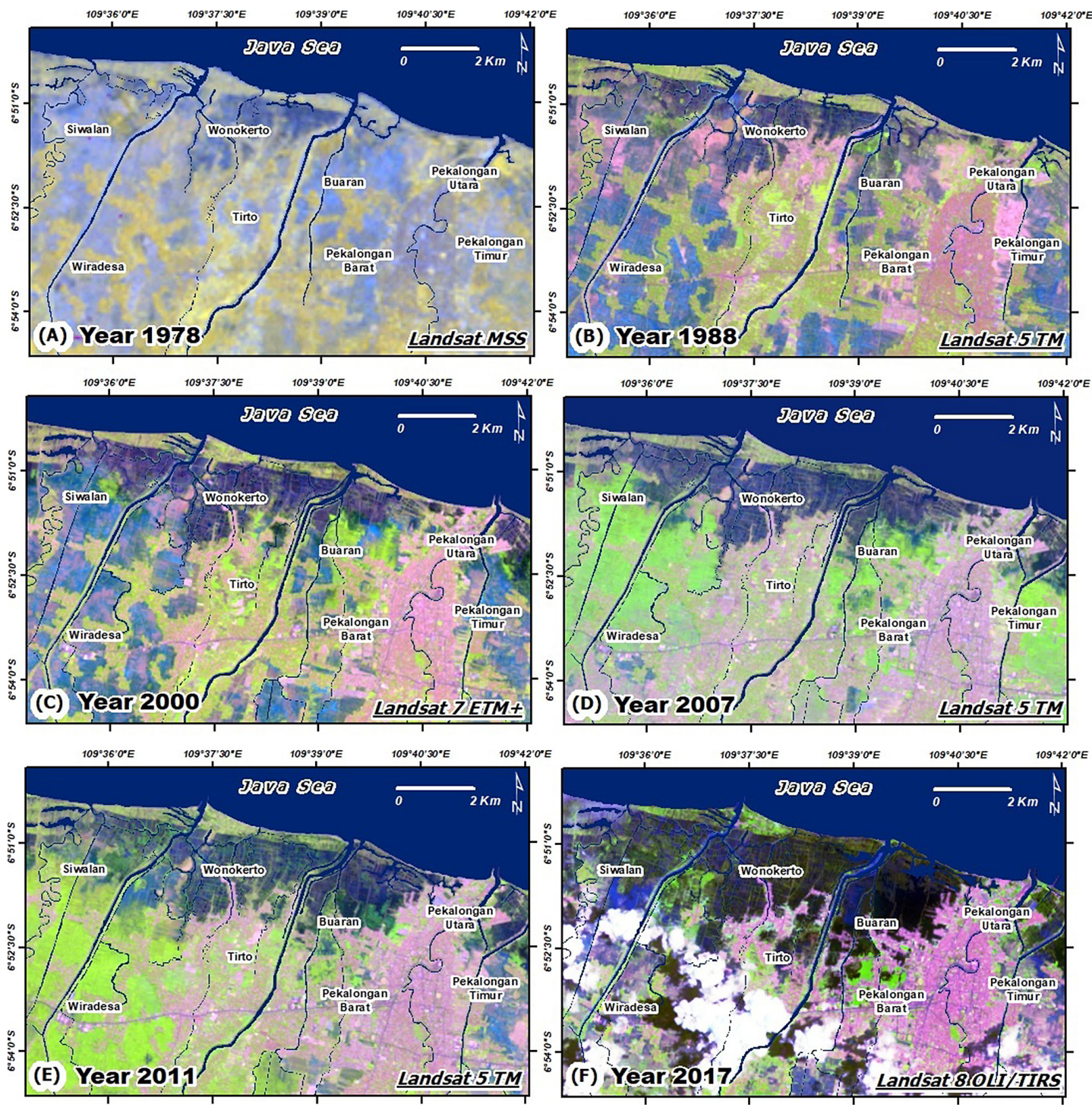

Fig. 2. Landsat images were used to perform coastal landform mapping, consisting of analysis of multitemporal changes in morphology for 1978 to 2017 in the study area.

A. Landsat MSS 1978; B. Landsat 5 TM 1988; C. Landsat 7 ETM+ 2000; D. Landsat 5 TM 2007; E. Landsat 5 TM 2011; F. Landsat 8 OLI/TIR 2017.

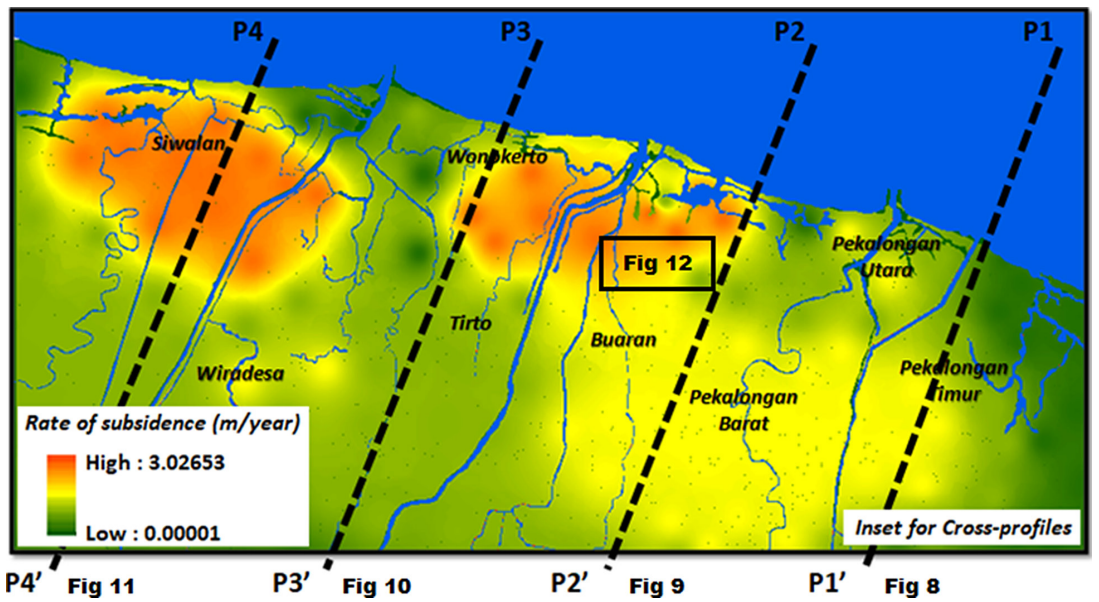

Fig. 3. The rate of subsidence ( $3 \mathrm{~cm} \mathrm{yr}^{-1}$ on average) was obtained based on research by Nashrrullah et al. (2013). Inset are locations for Fig. 8, 9, 10, 11, and 12. 
composites. Verstappen (1977) and Rao (2002) describe four phases of image interpretation for landform classification:

- detection,

- recognition and identification,

- analysis,

- classification of landform features.

In this study, the coastal landform classification system includes elements such as colour, texture, size, shape, relief, site, slope, land use and associated features of landform, as applied by Magesh et al. (2014). In addition, field surveys and other spatial data are also used to complement some of the parameters used for coastal landform classification, such as topography, relief, land use/land cover and others.

\section{Results}

\section{The dynamics of coastal topographical mapping and modelling}

In this study, topographic conditions can be represented and simplified using the DEM. The results of the dynamics of coastal topographical mapping and modelling from 1978 to 2017 in the study area are presented in Figure 4.

\section{Coastal landform mapping and change analysis}

In this study, the results of the mapping of change associated with coastal landform analysis
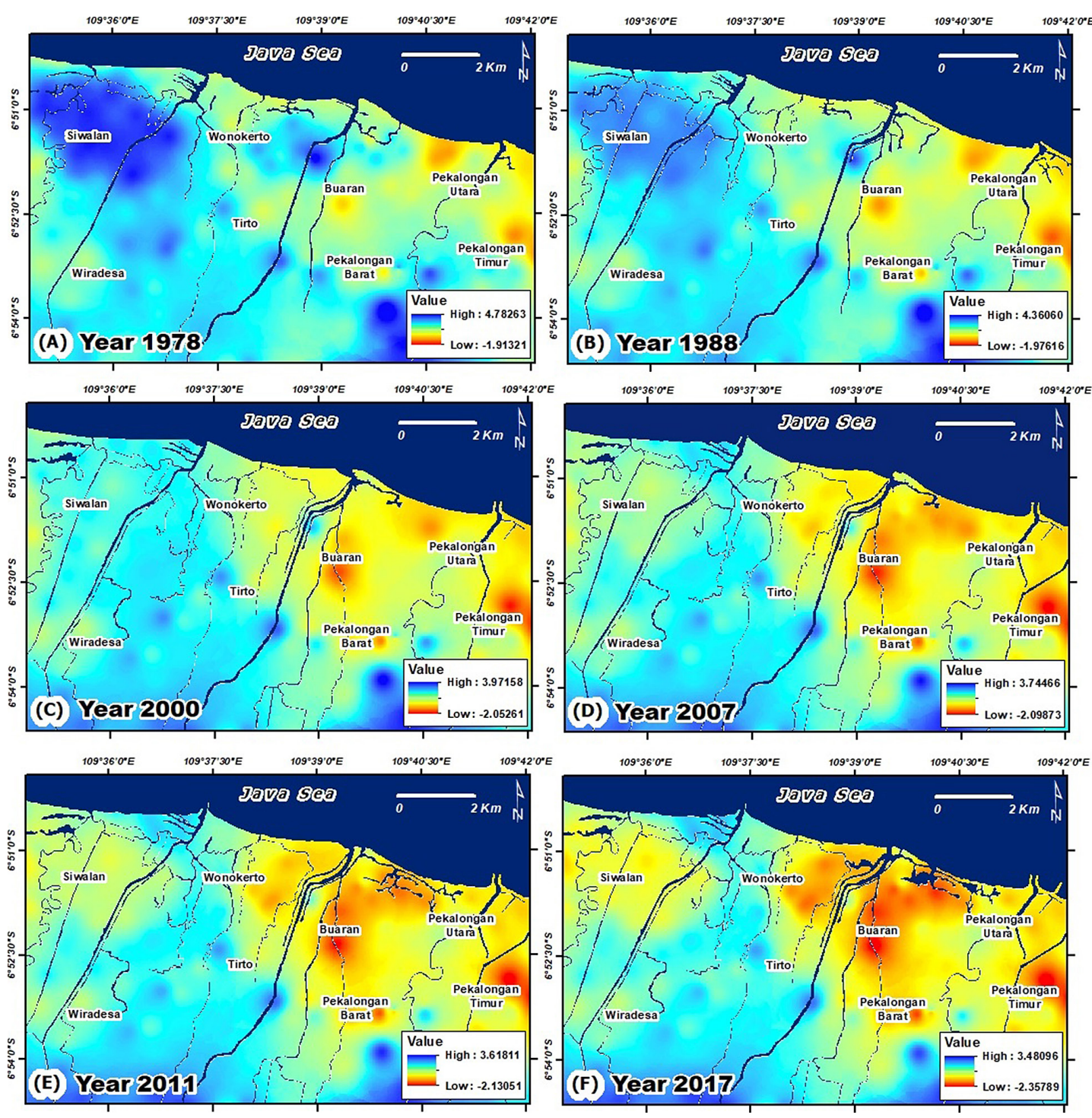

Fig. 4. The results of the dynamics of coastal topographical mapping and modelling for 1978 to 2017 in the study area. 
Table 1. Elements of coastal landform classification in the study area.

\begin{tabular}{|c|c|c|c|c|c|c|c|c|c|}
\hline \multirow{2}{*}{$\begin{array}{l}\text { Coastal } \\
\text { landform }\end{array}$} & \multicolumn{9}{|c|}{ Elements of the coastal landform classification } \\
\hline & Colour & $\begin{array}{l}\text { Tex- } \\
\text { ture }\end{array}$ & Size & Shape & Relief & Site & Slope & Land use & $\begin{array}{c}\text { Association of } \\
\text { features }\end{array}$ \\
\hline Beach & $\begin{array}{l}\text { bright } \\
\text { white }\end{array}$ & smooth & narrow & elongated & $\begin{array}{l}\text { flat/gently } \\
\text { shelving }\end{array}$ & $\begin{array}{l}\text { bordering } \\
\text { the sea }\end{array}$ & $0-3 \%$ & bare land & \multirow{3}{*}{$\begin{array}{l}\text { beach, beach } \\
\text { ridge and back } \\
\text { swamps asso- } \\
\text { ciate to form a } \\
\text { major land- } \\
\text { scape in the } \\
\text { coastal region }\end{array}$} \\
\hline Beach ridge & $\begin{array}{l}\text { bright } \\
\text { green }\end{array}$ & rough & narrow & elongated & undulating & $\begin{array}{l}\text { parallel to } \\
\text { the beach }\end{array}$ & $3-8 \%$ & $\begin{array}{l}\text { shrubs, } \\
\text { bushes, } \\
\text { croplands }\end{array}$ & \\
\hline Backswamp & blue & smooth & $\begin{array}{l}\text { exten- } \\
\text { sive }\end{array}$ & $\begin{array}{l}\text { elongated/ } \\
\text { long }\end{array}$ & flat & $\begin{array}{l}\text { behind the } \\
\text { beach ridges }\end{array}$ & $\begin{array}{l}0 \% \\
\text { (flat) }\end{array}$ & water & \\
\hline $\begin{array}{l}\text { Alluvial } \\
\text { plain }\end{array}$ & $\begin{array}{l}\text { bright } \\
\text { green, } \\
\text { blue, } \\
\text { red }\end{array}$ & rough & $\begin{array}{l}\text { very ex- } \\
\text { tensive }\end{array}$ & $\begin{array}{l}\text { elongated/ } \\
\text { wide and } \\
\text { long }\end{array}$ & $\begin{array}{l}\text { flat/gently } \\
\text { sloping }\end{array}$ & $\begin{array}{l}\text { behind } \\
\text { the back } \\
\text { swamps }\end{array}$ & $0-3 \%$ & $\begin{array}{l}\text { various, } \\
\text { dominated } \\
\text { by settle- } \\
\text { ments and } \\
\text { paddy } \\
\text { fields }\end{array}$ & $\begin{array}{l}\text { the main } \\
\text { depositional } \\
\text { landforms } \\
\text { bordering the } \\
\text { coastal region }\end{array}$ \\
\hline
\end{tabular}
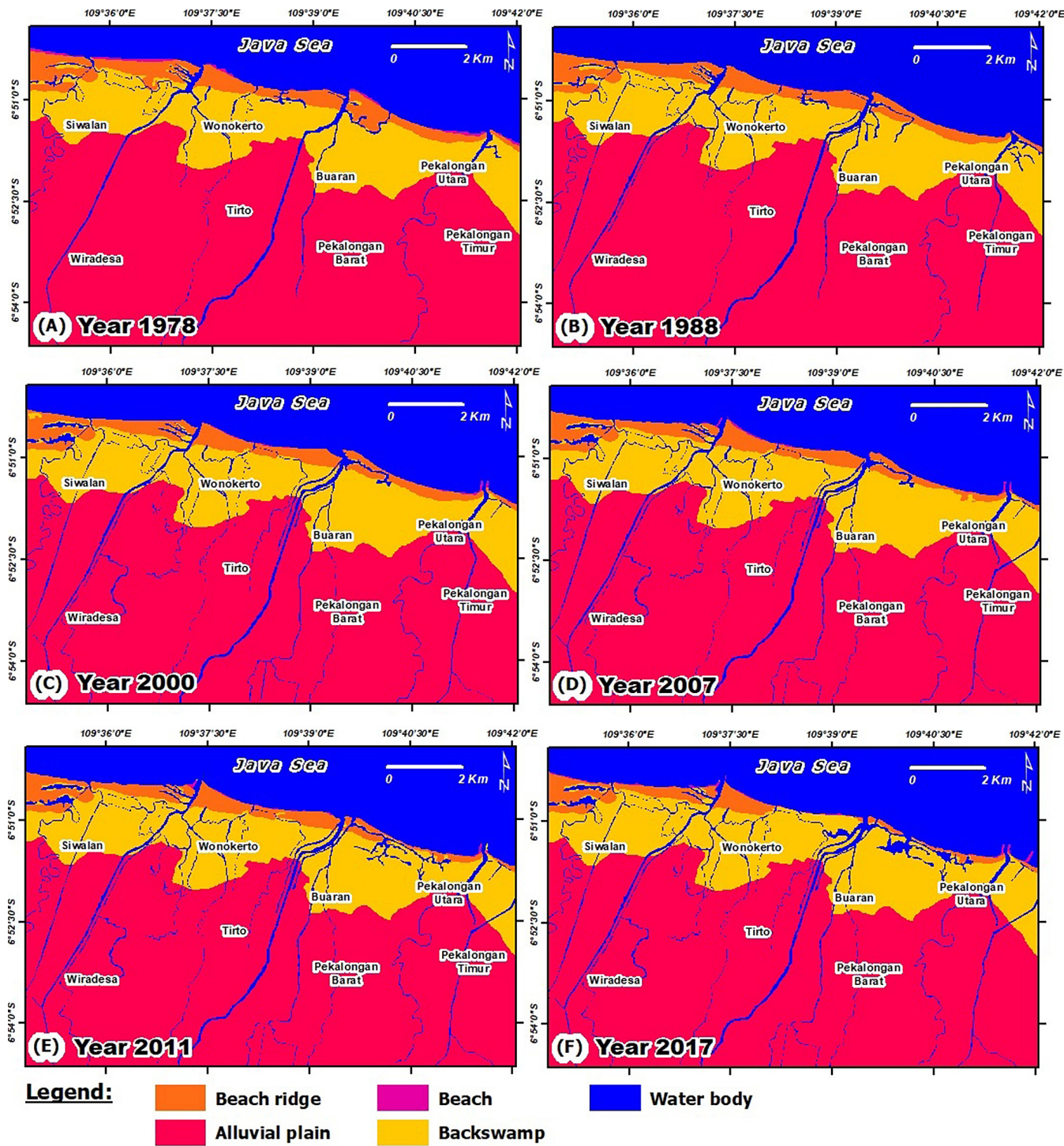

Fig. 5. The results of coastal landform mapping and change from 1978 to 2017 in the study area. 
Table 2. The estimated area of coastal landform change for 1978 to 2017 in the study area.

\begin{tabular}{|l|c|c|c|c|c|c|}
\hline \multirow{2}{*}{ Coastal landform } & \multicolumn{6}{|c|}{ Year } \\
\cline { 2 - 7 } & $1978(\mathrm{ha})$ & $1988(\mathrm{ha})$ & $2000(\mathrm{ha})$ & $2007(\mathrm{ha})$ & 2011 (ha) & 2017 (ha) \\
\hline Beach & 9 & 15 & 21 & 25 & 17 & 14 \\
\hline Beach ridge & 727 & 713 & 642 & 584 & 578 & 465 \\
\hline Backswamp & 2324 & 2333 & 2336 & 2359 & 2364 & 2379 \\
\hline Alluvial plain & 7763 & 7640 & 7495 & 7286 & 7260 & 7151 \\
\hline
\end{tabular}

Table 3. The estimate of the average rate area of coastal landform change for the year 1978 to 2017 in study area.

\begin{tabular}{|l|r|r|r|r|r|r|}
\hline \multirow{2}{*}{ Coastal landform } & \multicolumn{5}{|c|}{ Change area (ha) } & Average change area (ha $\mathrm{yr}^{-1}$ ) \\
\cline { 2 - 6 } & $1978-1988$ & $1988-2000$ & $2000-2007$ & $2007-2011$ & $2011-2017$ & $1978-2017$ \\
\hline Beach & +6 & +6 & +4 & -8 & -3 & +0.38 \\
\hline Beach ridge & -14 & -71 & -58 & -6 & -113 & -6.72 \\
\hline Backswamp & +9 & +3 & +23 & +5 & +15 & +1.41 \\
\hline Alluvial plain & -123 & -145 & -209 & -26 & -109 & -15.69 \\
\hline
\end{tabular}

+ - increase, - - decrease.

can be classified into four landform types: beach, beach ridge, backswamp and alluvial plain, based on visual and digital interpretation of Landsat colour composite images from 1978 to 2017. In addition, coastal landform classification can be complemented by parameters based on the field surveys and other spatial data, such as topography, relief, land use/land cover, soil and others. The elements of coastal landform classification and other parameters are presented in (Table 1), while the results of coastal landform mapping in the study area are presented in (Fig. 5). Based on the results of coastal landform mapping and change from 1978 to 2017, the estimated areas of coastal landform change for 1978 to 2017 in the study area are as presented in (Table 2) Meanwhile, the estimate of the average rate of coastal landform area change for 1978 to 2017 is presented in (Table 3).

\section{The effect of coastal landform change and related implications of tidal flood impact in the study area}

In general, the characteristics of the coastal landform profile in the study area are as presented in (Fig. 6). An example of the conditions of coastal landforms in the study area can be seen in (Fig. 7). In addition, coastal landform change can also be caused by the influence of land subsidence. The topographic modelling carried out in this research shows that the topographic changes caused by land subsidence have changed the coastal landform classes in several locations in

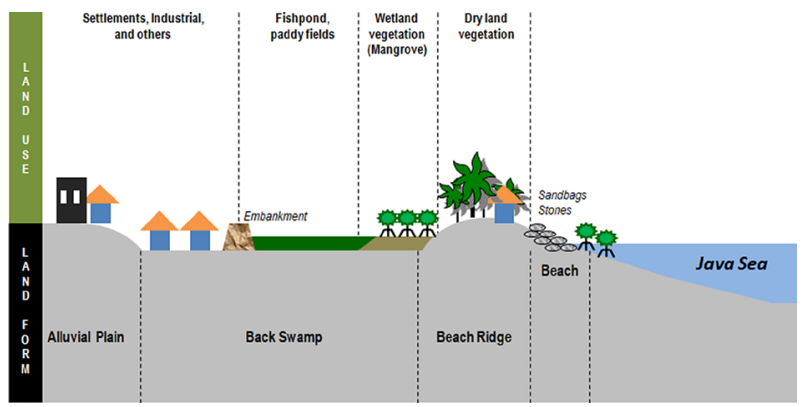

Fig. 6. The relationship between coastal landform profile and land use in the study area.

the study area. Vertically, topographic changes based on scenarios of land subsidence are presented in (Figs 8-11), while the location inset is presented in (Fig. 3).

Comparisons of morphological and topographic change through DEM modelling between 1978 and 2017 for cross-profiles 1 to 4 are

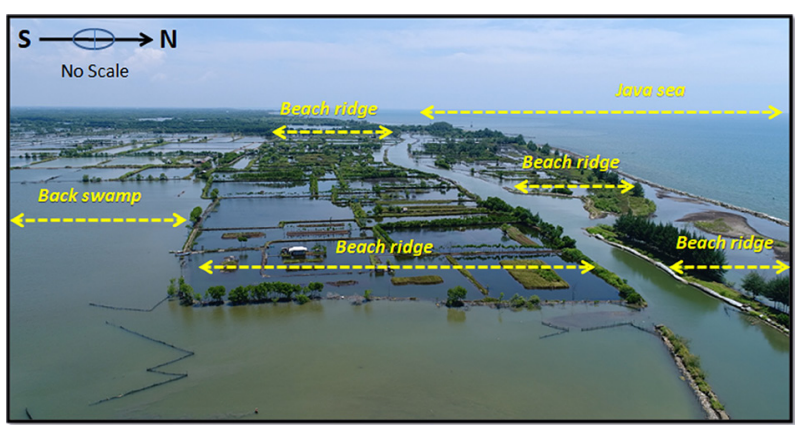

Fig. 7. Landform coastal conditions in 2017 in the study area. The beach ridge, which has an important role as a natural embankment in coastal areas, has been changed into a flat area and is used by local people for ponds (Photo: F. Yulianto 2017). 


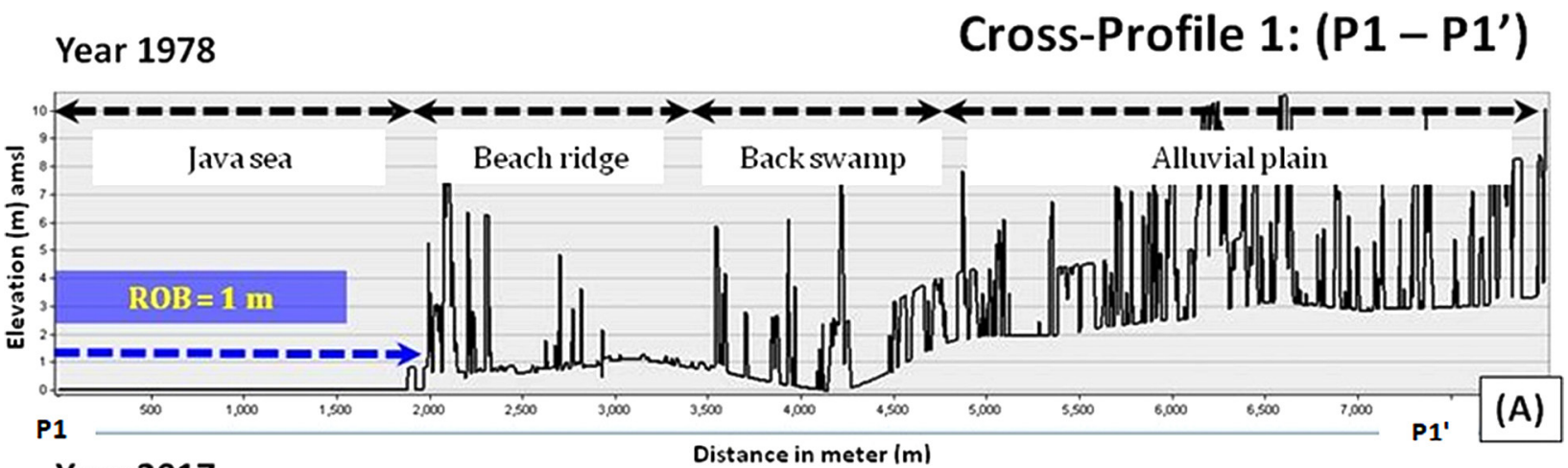

Year 2017

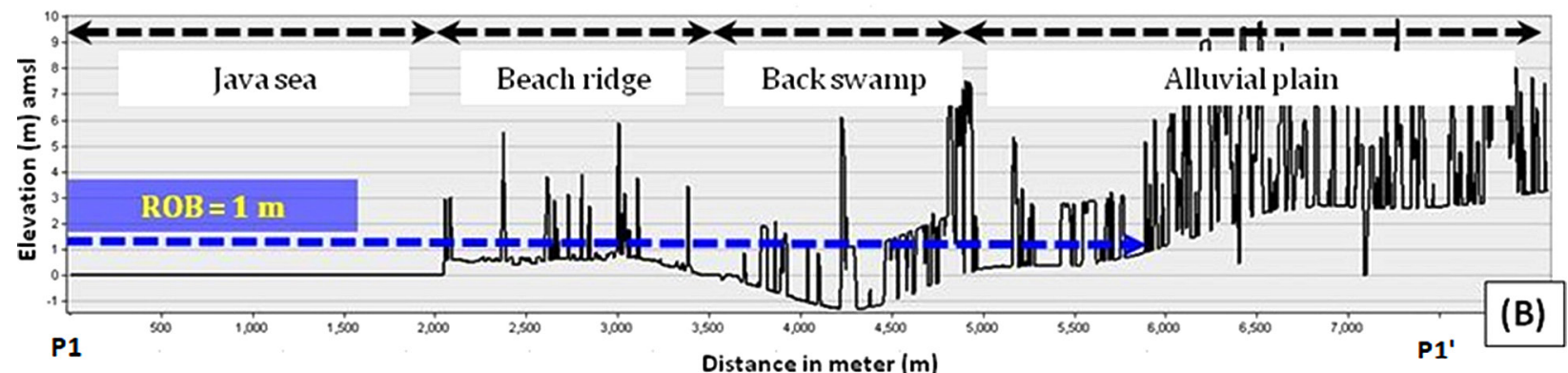

Fig. 8. Comparison results for morphological and topographic condition change from DEM modelling between 1978 and 2017 on cross-profile 1 (P1-P1') and their implications for vertical tidal flood distribution in coastal landform areas.

A. DEM cross-profile 1 in 1978; B. DEM cross-profile 1 in 2017.

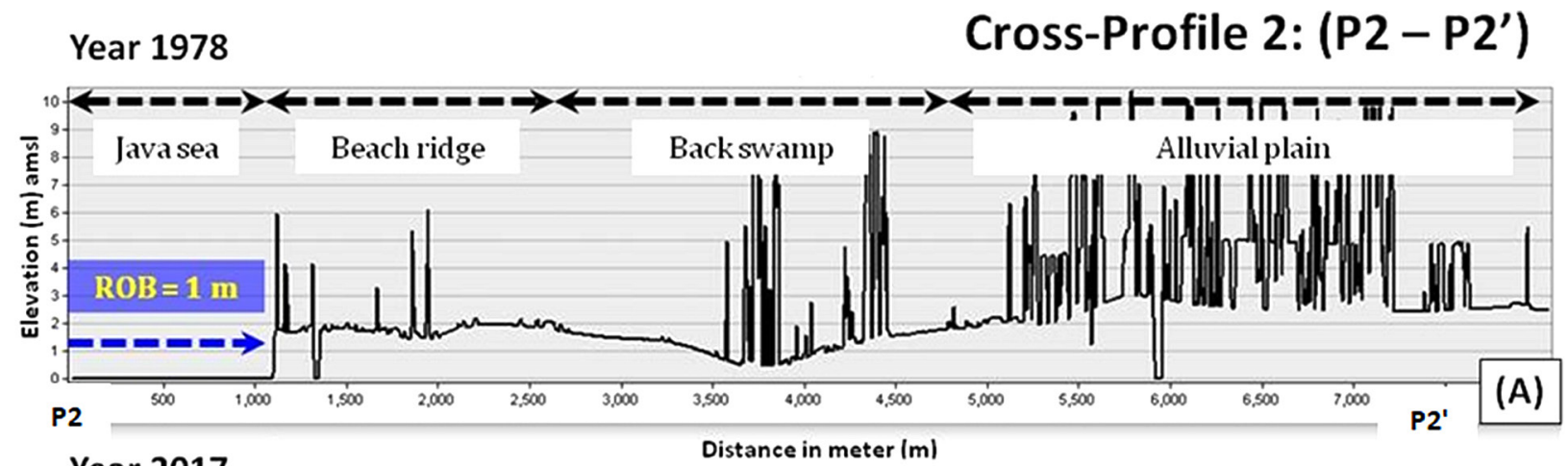

Year 2017

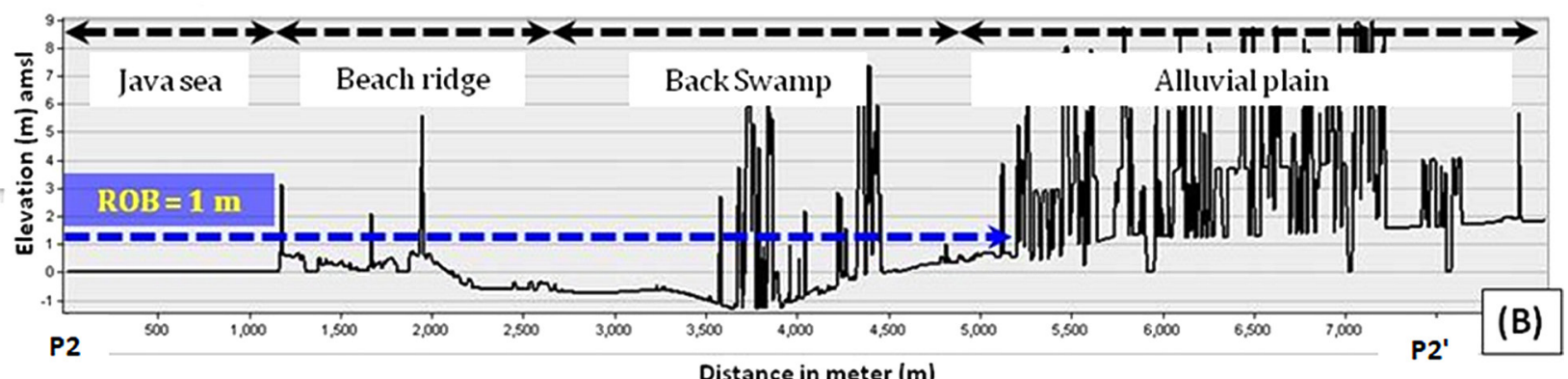

Fig. 9. Comparison results for morphological and topographic condition change from DEM modelling for 1978 and 2017 for cross-profile 2 (P2-P2') and their implications for vertical tidal flood distribution in coastal landform areas.

A. DEM cross-profile 2 in 1978; B. DEM cross-profile 2 in 2017. 

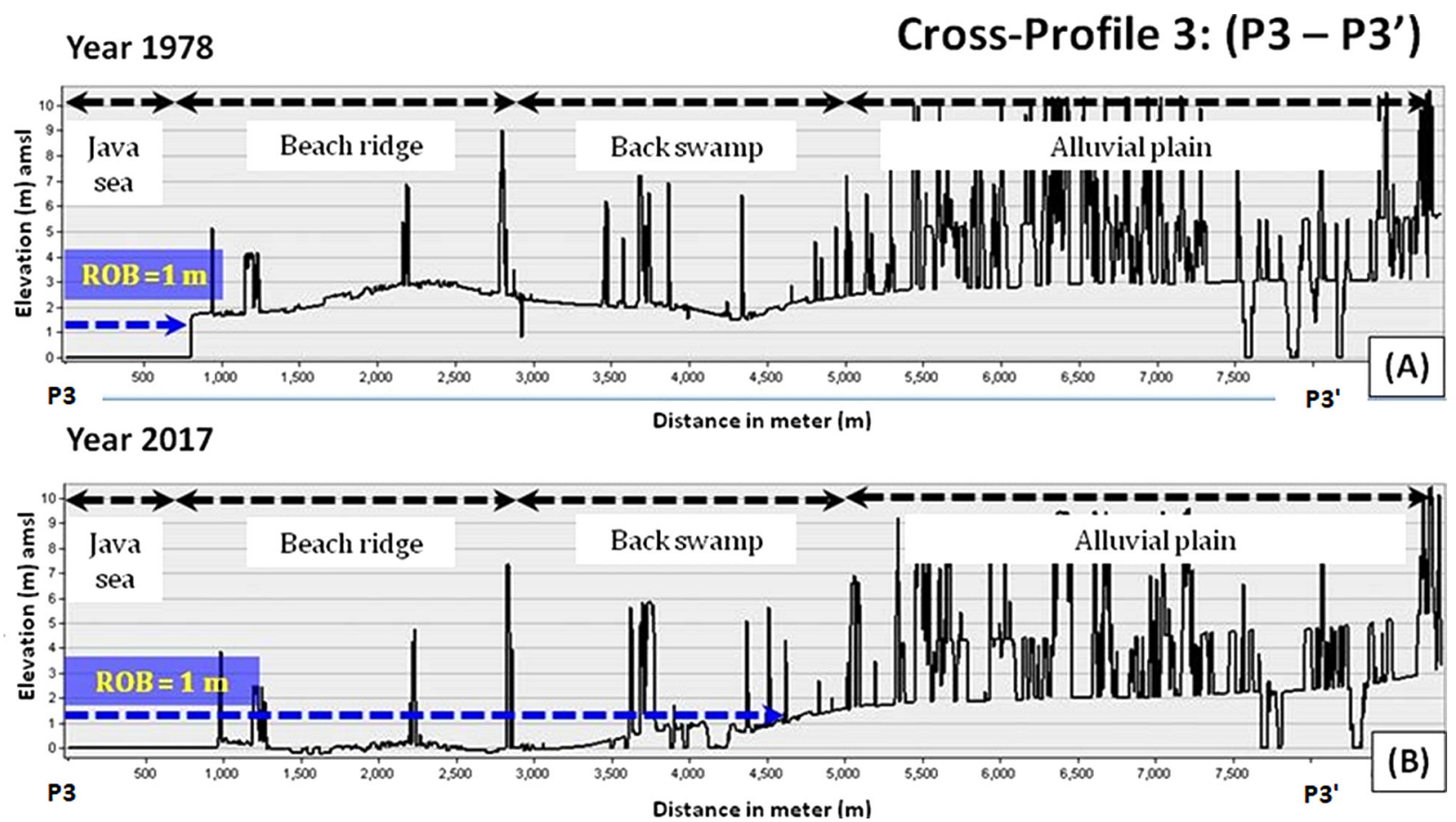

Fig. 10. Comparison results for morphological and topographic condition change from DEM modelling between 1978 and 2017 on cross-profile 3 (P3-P3') and their implications for vertical tidal flood distribution in coastal landform areas.

A. DEM cross-profile 3 in 1978; B. DEM cross-profile 3 in 2017.

Year 1978

Cross-Profile 4: (P4 - P4')
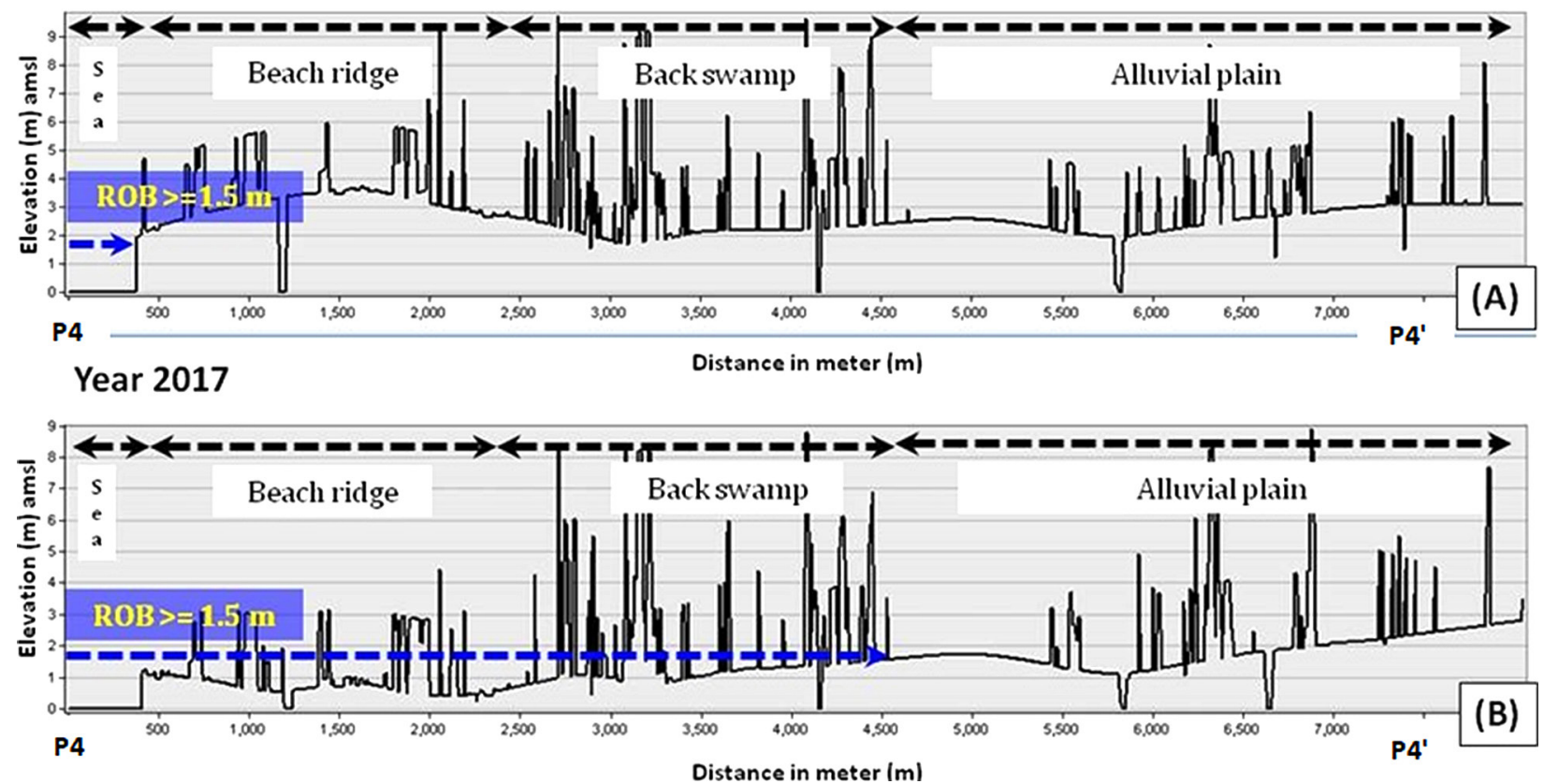

Fig. 11. Comparison results for morphological and topographic condition change from DEM modelling between 1978 and 2017 on cross-profile 4 (P4-P4') and their implications for vertical tidal flood distribution in coastal landform areas.

A. DEM cross-profile 4 in 1978; B. DEM cross-profile 4 in 2017. 


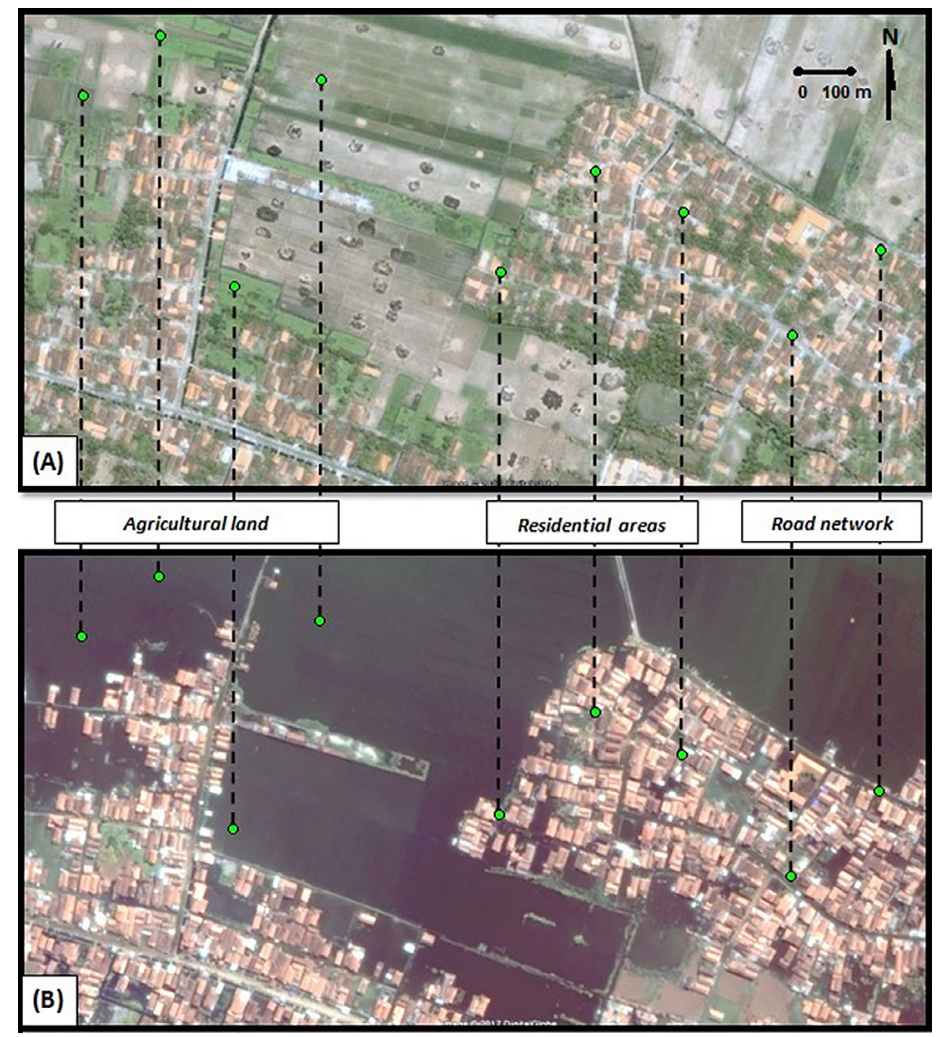

Fig. 12. Areas affected by flooding, such as agricultural land, residential areas and road networks in Jeruksari Village, Tirto District, Pekalongan Regency. (Source: Google Earth; CNES (the French space agency)).

A. Environmental conditions pre-tidal flood, 22 October 2006; B. Flooded conditions during/post-tidal flood, 28 April 2017.
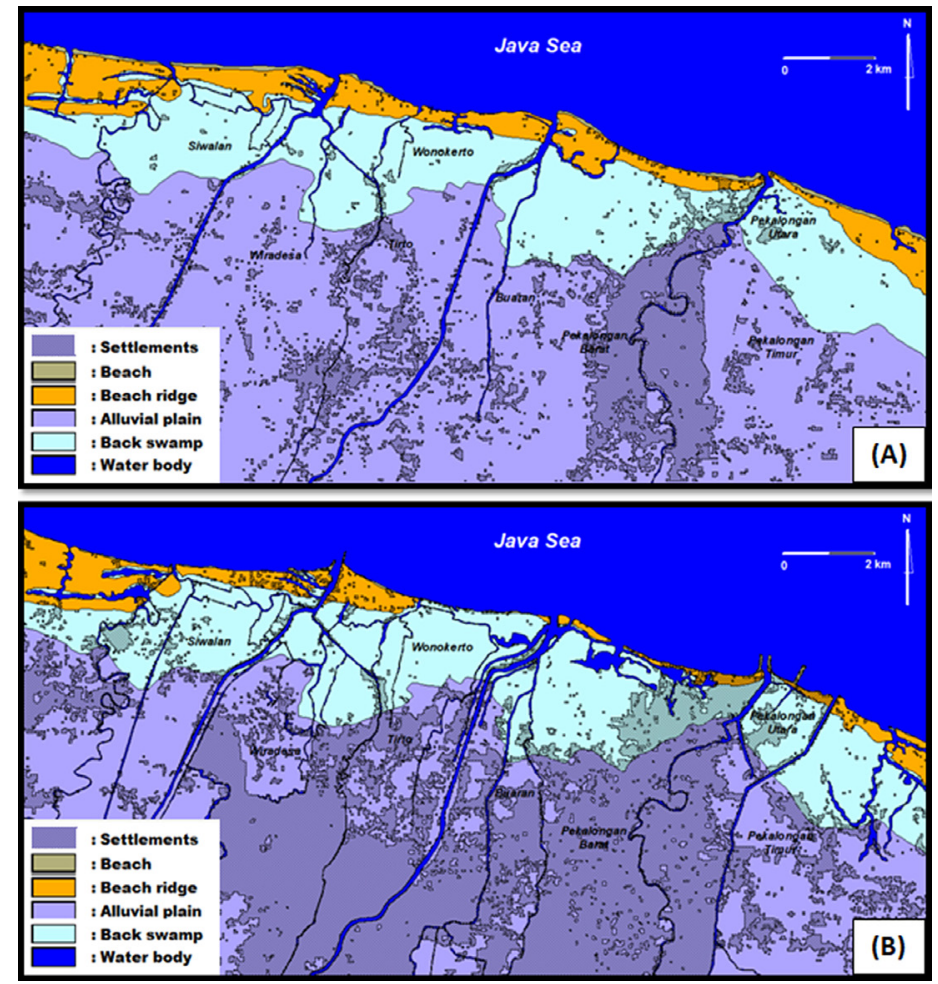

Fig. 13. Comparison of settlement distribution located on coastal landform between 1978 and 2017 in the study area.

(A) Settlement on coastal landforms in 1978; (B) Settlement on coastal landforms in 2017. 
Table 4. Settlements and average area comparisons for coastal landforms for 1978 and 2017 in the study area.

\begin{tabular}{|c|c|c|c|}
\hline \multirow[b]{2}{*}{$\begin{array}{l}\text { Coastal } \\
\text { landform }\end{array}$} & \multicolumn{2}{|c|}{ Year } & \multirow{2}{*}{$\begin{array}{c}\text { Average area of } \\
\text { increase }\left({\left.\text { ha } \mathrm{yr}^{-1}\right)} \text { ) }\right. \\
1978 \text { to } 2017\end{array}$} \\
\hline & $\begin{array}{c}1978 \text { area } \\
\text { (ha) }\end{array}$ & $\begin{array}{c}2017 \text { area } \\
\text { (ha) }\end{array}$ & \\
\hline Beach & 0.08 & 6.36 & 0.16 \\
\hline Beach ridge & 25.24 & 66.11 & 1.05 \\
\hline Backswamp & 99.54 & 396.90 & 7.63 \\
\hline $\begin{array}{l}\text { Alluvial } \\
\text { plain }\end{array}$ & 1388.75 & 3962.76 & 66.01 \\
\hline
\end{tabular}

presented in (Figs 8-11). It can be seen that beach ridges play an important role as natural dykes that serve to withstand flooding. In 1978 a tidal flood with a height of $1 \mathrm{~m}$ was retained by the beach ridge, while in 2017, with land subsidence having impacted on topography, $1 \mathrm{~m}$ flooding could not be restrained by the beach ridge and the flood tide was distributed across land areas by up to between 3 and $5 \mathrm{~km}$ inland.

Figure 12 shows some of the locations affected by tidal flooding in the study area, such as agricultural land, residential areas and settlements, roads and others (location inset is as in (Fig 3). Locations up to about $2 \mathrm{~km}$ from the coastline and on the backswamp appear to be flooded by tidal waters, spatially presented based on the comparison of satellite image recordings on 22 October 2006 (pre-flood) and 28 April 2017 (during/postflood). As shown in (Fig. 13) and (Table 4) it can be seen that under the same conditions there are about 99.54 ha of backswamp in 1978 and 396.90 ha of backswamp in 2017, with the average in-

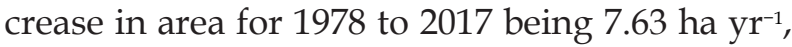
the location of settlements potentially affected by tidal flooding as it is located on the coastal landform on the backswamp class.

\section{Discussion}

In this study, the dynamics of coastal topographical mapping and modelling can be described using topographic conditions. It can be represented and simplified using the DEM. Topographic mapping was performed on the basis of high-point interpolation of 1:25,000 scale topographic data for 1998. To determine the topographic conditions for 1978 to 2011 (DEM current conditions in 2017 and previous years of 1978, 1988, 2000, 2007 and 2011) topographic modelling as used by Marfai and King (2007) was implemented. The rate of subsidence (i.e. $3 \mathrm{~cm} \mathrm{yr}^{-1}$ ) stated by Nashrrullah et al. (2013) was used as a reference in this study. The modelling was assumed to be linear in every year, which means no action or treatment of subsidence issues took place in the study area. Marfai and King (2007) and Ward et al. (2010) have applied the method for monitoring land subsidence in Semarang and Jakarta, respectively. The same method was applied in this study because it has almost the same regional characteristics. Not only for monitoring and modeling land subsidence, but also this study was carried out aimed to trace and map historically the dynamics of topographical change. The results of the analysis from (Fig. 4) show that high-value DEM data (3.4 to $4.7 \mathrm{~m}$ above sea level from 1978 to 2017) show a relatively stable area and little effect on the problem of land subsidence. Meanwhile, low-value DEM data ( -1.9 to $-2.3 \mathrm{~m}$ above sea level in years 1978 to 2017) show the areas most influenced by land subsidence problems in the study area.

Coastal landforms can be classified into four landform types in this study, namely: beach, beach ridge, backswamp and alluvial plain. Multi-temporal coastal landform change analysis for 1978 to 2017 was used to historically determine the condition of landforms and the environment. Coastal landform mapping and change analysis have been carried out based on the integration of remote sensing data and GIS. The visual interpretation approach was applied in this study, as was done by Shalaby and Tateishi (2007); Zhao et al. (2008). The years 1978 to 1988 were represented the best condition of coastal landforms in the region; this period is therefore used as the starting point for this study to present the situation before there was a problem of tidal flooding in the area. In the period 2000 to 2011, the condition of coastal landforms changed, but tidal flooding did not have a large impact. However, from 2011 to 2017, issues related to flooding have had a major impact on coastal landforms in the study area. This has been described by Maulana (2012) and Kasbullah and Marfai (2014) that the Pekalongan coastal area has serious tidal flood problems. Based on the results of coastal landform mapping and change analysis can be seen that beach ridge and alluvial 
plain decreased from 1978 to 2017, with the average change of area of -6.72 and $-15.69 \mathrm{ha} \mathrm{yr}^{-1}$, respectively. Meanwhile, beach and backswamp landforms increased from 1978 to 2017, with an

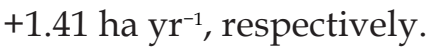

In coastal areas, every landform class has a land use/land cover that can the surrounding environment. For example, land use/land cover such as settlement areas should ideally be designed to be in locations topographically higher than surrounding sites, i.e., alluvial plains and beach ridges. However, there are several settlements located in the basin area, i.e., in the backswamp. Under these conditions, some residential locations are potentially affected by tidal flooding. Meanwhile, the existence of land use/ land cover in the form of ponds on the backswamp has extended from year to year. Some community behavior has damaged and changed the beach ridge and beach areas into pond locations. The beach ridge has a very important role as a natural embankment that can inhibit waves and the flow of seawater into the land area. According to Marfai (2014) that predicted the impact of a tidal flood to ecosystems in Pekalongan consists of increasing coastal erosion, increasing coastal flooding, damage on mangrove ecosystem, fishpond/ aquaculture, and agriculture.

Based on the results and field surveys, the causes of tidal flooding in the Pekalongan coastal area are:

- morphological and topographic changes which have occurred to beach ridges (acting as natural embankments) during the period 1978 to 2017. This is related to land use/land cover change including land clearing for pond areas accompanied by the making of channels connecting rivers, sea and pond areas,

- there has been land subsidence that has had a major influence on morphological and topographical changes in coastal landforms in the study area. This has been caused by the increasing number of settlements and excessive groundwater extraction activities,

- there has been the use of flood-prone areas (backswamp) for residential areas,

- the wave-retaining dykes are unable to restrain seawater from entering the land because of morphological or topographical changes to the beach ridges in their role as natural embankments in coastal areas.
In light of these issues, there needs to be a serious effort led by the government of Indonesia to involve all components, for the mitigation of tidal flooding resulting from the impact of human activity. Conservation programmes in the Pekalongan coastal area are needed to restore the natural condition of coastal areas by reconstructing and revitalizing natural embankments/ beach ridges and replanting mangroves. These efforts could certainly reduce the impact of tidal flooding in the study area. In addition, it is also necessary to place pond areas in accordance with morphological conditions or topography (i.e. in backswamp areas).

This study has limitations in that it investigates the physical characteristics of coastal landform to trace only one of the factors causing tidal flooding in the research area. Other studies of social, economic and environmental conditions need to be carried out to enable comprehensive exploration of the phenomenon of tidal flooding in the study area. In addition, the results of this study are supported by spatial data information at a mapping scale of 1:25,000. Further research could be carried out using information from other remote sensing data (SPOT 6/7, Pleiades, Ikonos, Quick bird, and others) to support spatial data information at mapping scales of 1:5,000 to 1:10,000.

\section{Conclusion}

This study has contributions and shown the capability of remote sensing and GIS techniques in tracing the dynamics of coastal landform change along Pekalongan coastal area. The result of the study also pointed out that there is a relationship between these changes and the current occurrences of tidal flooding in the study area. Although, this study has succeed to prove the capability of remote sensing and GIS technique to find out the major causes of the frequent current accurrences of tidal floods in Pekalongan coastal area. In order to get more comprehensive study for preventing the areas and the economic society for living to be worst and support the implementation that the goverment should do this research should be continued. The next research is recommended to study of the socio-economy, environment and preparing the planning for the impact areas spatially. 


\section{Acknowledgements}

This paper is part of the research activities entitled The utilization of remotely sensed data to support analysis of flooding in Indonesia. This research was funded by the budget of DIPA LAPAN activities in 2017, Remote Sensing Application Center, Indonesian National Institute of Aeronautics and Space (LAPAN). Thanks go to Dr Mujio Sukir, Dr Indah Prasasti, Gigih Giarrastowo and Tival Gorodas and colleagues at the Remote Sensing Application Center, LAPAN for their support, discussions and suggestions. Landsat 5 MSS and Landsat 7 TM images were provided by the US Geological Survey (USGS), Landsat 8 OLI/ TIR images were provided by Remote Sensing Technology and Data Center, LAPAN and topographic maps were provided by the Indonesian Geospatial Information Agency (BIG).

\section{Author's Contributions}

Conceptualization: F.Y., S., T.M.; Methodology: F.Y., S., T.M., M.R.K.; Validation: F.Y., S., T.M.; Formal Analysis: F.Y., S., T.M., M.R.K.; Writing-Original Draft Preparation: F.Y., S.; Writing-Review \& Editing: F.Y., S., T.M., M.R.K.; Visualization: F.Y., S.

\section{References}

Bemmelen R.W., 1949. The Geology of Indonesia. The Hague. Govt. Printing Office, Lolage.

Blaszczynski J.S., 1997. Landform characterization with geographic information systems. Photogrammetric engineering and remote sensing 63(2): 183-191.

Brooks S., 2007. Geomorphological processes. The London School of Economics and Political Science. University of London.

Chandrasekar N., Cherian A., Rajamanickam M., Rajamanickam, G.V., 2000. Coastal landform mapping between Tuticorin and Vaippar using IRS-IC data. Indian Journal of Geomorphology 5(1\&2): 115-122.

Condon W.H., Pardyanto L., Ketner K.B., Amin T.C., Gafoer S., Samodra H., 1996. Geological Map of Sheet Banjarnegara and Pekalongan, Central Java. Bandung. Peta Geologi Lembar Banjarnegara dan Pekalongan, Jawa Tengah. Bandung.

Davidson-Arnott R.G.D., 2010. Introduction to coastal processes and geomorphology. United States of America by Cambridge University Press, New York.

Ekercin S., 2007. Coastline Change Assessment at the Aegean Sea Coasts in Turkey Using Multitemporal Landsat Imagery. Journal of Coastal Research 23(3): 691-698.

Erkkilä A., Kalliola R., 2004. Patterns and dynamics of coastal waters in multi-temporal satellite images: support to water quality monitoring in the Archipelago Sea, Finland. Estuarine, Coastal and Shelf Science 60(2): 165-177.

Ismail N.P., 2012. The dynamics of changes in the coastline of Pekalongan and Batang, Central Java. Thesis. Faculty of
Fisheries and Marine Science. Dinamika perubahan garis pantai Pekalongan dan Batang, Jawa Tengah. Skripsi. Fakultas Perikanan dan Ilmu Kelautan. Institut Pertanian BogorBogor Agricultural University.

Kaliraj S., Chandrasekar N., Ramachandran K.K., 2017. Mapping of coastal landforms and volumetric change analysis in the south west coast of Kanyakumari, South India using remote sensing and GIS techniques. The Egyptian Journal of Remote Sensing and Space Sciences 20(2): 265-282. DOI: 10.1016/j.ejrs.2016.12.006.

Kasbullah A.A., Marfai M.A., 2014. Spatial modeling of tidal flood inundation and assessment of potential losses on paddy fields, case studies of coastal areas in Pekalongan District, Central Java. Geoedukasi 3(2): 83-91.

Kuleli T., Guneroglu A., Karsli F., Dihkan M. 2011. Automatic detection of shoreline change on coastal Ramsar wetlands of Turkey. Ocean Engineering 38(10): 1141-1149.

Lambin E.F., Strahlers A.H., 1994. Change-vector analysis in multitemporal space: a tool to detect and categorize land cover change processes using high temporal-resolution satellite data. Remote sensing of environment 48(2): 231-244.

Magesh N.S., Chandrasekar N., Kaliraj S., 2014. Mapping the coastal geomorphological landforms through Aster DEM and Landsat data - a case study from TuticorinVembar coastal stretch, southeast coast of India. Journal of Coastal Sciences 1(1): 1-5.

Marfai M.A., 2014. Impact of sea level rise to coastal ecology: a case study on the northern part of Java Island, Indonesia. Quaestiones Geographicae 33(1): 104-114. DOI: 10.2478/quageo-2014-0008.

Marfai M.A., King L., 2007. Monitoring land subsidence in Semarang, Indonesia. Environmental Geology 53: 651-659. DOI: $10.1007 /$ s00254-007-0680-3.

Marfai M.A., Almohammad H., Dey S., Santoso B., King L., 2007. Coastal dynamic and shoreline mapping: multi-sources spatial data analysis in Semarang Indonesia. Environmental Monitoring and Assessment 142(1-3): 297308. DOI: 10.1007/s10661-007-9929-2.

Maulana S., 2012. Spatial Modeling for Prediction of Inundation Area of Tidal Floods in Coastal Areas of the City of Jakarta (Case Study: Tanjungpriok District, North Jakarta). Thesis. Faculty of Geography, Gadjah Mada University.

Nashrrullah S., Aprijanto, Pasaribu J.M., Hazarika M.K., Samarakoon L., 2013. Study on flood inundation in Pekalongan, Central Java. International Journal of Remote Sensing Earth Sciences 10(2): 76-83.

Rao D.P., 2002. Remote sensing application in geomorphology. Tropical ecology 43(1): 49-59.

Shalaby A., Tateishi R., 2007. Remote sensing and GIS for mapping and monitoring land cover and land-use changes in the Northwestern coastal zone of Egypt. Applied Geography 27(1): 28-41.

Verstappen H.Th., 1977. Remote Sensing in Geomorphology. Elseviers, Amersterdam.

Nayak S, Chauhan P, Chauhan HP, Bahuguna A, and Nath NA (1996) IRS-1C applications for coastal zone management. Current Science 70(7): 614-618.

Ward P.J., Marfai M.A., Yulianto F., Hizbaron D.R., Aerts J.C.JH., 2010. Coastal inundation and damage exposure estimation: a case study for Jakarta. Natural Hazards 56: 899-916.

Zhao B., Guo H., Yan Y., Wang Q., Li B., 2008. A simple waterline approach for tidelands using multi-temporal satellite images: A case study in the Yangtze Delta. Estuarine, Coastal and Shelf Science 77(1): 134-142. 